\title{
Conservation Agriculture Approaches in Banana to Improve Soil Quality and Farm Productivity
}

\author{
S.N. Dash*, S. Behera, Y. Pushpavathi and K.N. Mishra \\ Orissa University of Agriculture and Technology, Bhubaneswar-751003, India \\ *Corresponding author
}

\section{A B S T R A C T}

\section{Keywords \\ Agriculture, Soil quality, Banana}

Article Info

Accepted:

07 February 2018

Available Online:

10 March 2018
In an investigation carried out at the Horticultural Research Station of Orissa University of Agriculture and Technology, Bhubaneswar during 2012-13 and 2013-14 banana was tried along with 4 intercrops, Glyricidia maculeata leaf manure and polyethylene mulch to mitigate the effects of reducing soil quality and productivity and improve farm profitability. Green manuring crops in the banana plantation improved soil organic carbon, microbial biomass carbon and available nutrients of the soil besides maintaining overall soil quality. The leguminous cowpea yielded highest total banana equivalent yield $(41.37 \mathrm{t}$ $\mathrm{ha}^{-1}$ ) and fetched highest net return (Rs. $231723 \mathrm{ha}^{-1}$ ) but horsegram achieved highest cost: benefit ratio due to its low cost of cultivation.

\section{Introduction}

Indian agriculture has made great strides in achieving increased food grain production albeit at a low level of satisfaction. Increasing production has also been unwantedly accompanied by widespread problems of resource degradation, which now pose a serious challenge to the continued ability to meet the demand of an increasing population coupled with nutritional security.

The past strategies to increase food grain production, however, have resulted in massive exploitation of natural resources, contributing to unsustainable growth; there is a need to change this in the future. There has been continuous neglect of vast areas under rainfed agriculture, where productivity continues to remain low. These are the areas where vast majority of the poor live. Rainfall regimes and soil characteristics are the key determinants of rainfed cropping potential. In the absence of cost effective moisture retention and conservation technologies the soil suffers from rapid water runoff and erosion reducing the productive capacity. Persistent use of conventional farming practices based on extensive tillage combined with in situ burning of crop residues have magnified soil erosion losses and degradation of soil resource base steadily. Conservation agriculture which relies on practices that help to maintain ecological equilibrium and encourage natural regenerative processes, such as nitrogen fixation, nutrient recycling, soil regeneration and protection of natural enemies of pest and 
diseases as well as targeted use of inputs has come up as a new paradigm to achieve the goal of sustained agricultural production.

Banana has been utilized as a major fruit crop in many tribal dominated farming situations. In the degraded land management systems of the tribal areas leguminous intercrops/ cover crops can provide quick soil coverage and check soil erosion, add crop residues and cast favourable influence on many main crops, besides, providing additional returns (Yadukumar, 2007). Therefore, the present investigation was undertaken to find out the effects of various intercrops on soil properties, residual soil fertility, nutrient uptake, productivity and profitability in a banana based cropping system.

\section{Materials and Methods}

The study was carried out at the Horticultural Research Station, University of Agriculture and Technology, Bhubaneswar $\left(20^{\circ} 15^{\prime} \mathrm{N}\right.$ and longitude of $85^{\circ} 52^{\prime} \mathrm{E}$ and $25.5 \mathrm{~m}$ above mean sea level), Odisha from June, 2011 to June, 2013. The climate is hot and humid with a mean annual rainfall of $1450 \mathrm{~mm}$. The soil of the experimental site was sandy loam in texture, slightly acidic with a $\mathrm{pH}$ of 5.5, organic carbon of $6.0 \mathrm{~g} \mathrm{~kg}^{-1}$ and available NPK of $273.1,10.5$ and $93.6 \mathrm{~kg} \mathrm{ha}^{-1}$, respectively. Mean annual rainfall at the site averages $1450 \mathrm{~mm}$, unimodally distributed, with the rainy season lasting from mid-June to September. The experimental design was a complete randomized block with four replications. The seven treatments included four intercrops, one polyethylene mulch, green manuring of Glyricidia maculeata and a control without any intercrop or mulch in the interspaces of banana plants. At the end of summer season the field was laid out after a minimum primary tillage. Cv. Bantal of banana was used as the test variety.

The spacing adopted for banana plants was 2.2 m X $2.0 \mathrm{~m}$. Each banana plant received a recommended fertilizer dose of 200:50:200 g $\mathrm{N}, \mathrm{P}$ and $\mathrm{K}$ in form of Urea, Diammonium Phosphate and Muriate of Potash. The intercrops were sown/planted two weeks after the planting of banana. Glyricidia leaves were added as mulch in $\mathrm{T}_{5} @ 5 \mathrm{t} \mathrm{ha}^{-1}$ twice at an interval of 15 days starting from 30 days after planting (DAP). Except fertilizer application the soil was not disturbed in any other stage of the crop as the experiment was conducted on the principles of conservation agriculture.

The details of treatments are as under.

$\mathrm{T}_{1}$ : Banana + Cowpea,

$\mathrm{T}_{2}$ : Banana + Horsegram,

$\mathrm{T}_{3}$ : Banana + Bottle gourd,

$\mathrm{T}_{4}$ : Banana + Sweet potato,

$\mathrm{T}_{5}$ : Banana + Glyricidia maculeata incorporation @ 5tha-1

$\mathrm{T}_{6}$ : Banana + Polythene mulch,

$\mathrm{T}_{7}$ : Banana (Control)

The soil samples from individual experimental plots drawn from a depth of $0-15 \mathrm{~cm}$ after the end of $2^{\text {nd }}$ cropping cycle were placed in plastic bags and brought to the laboratory immediately for analysis. A portion of fresh soil samples were sieved through a $2 \mathrm{~mm}$ sieve and stored at $4^{0} \mathrm{C}$ for determination microbial biomass carbon (MBC). The MBC was measured by determining the organic carbon in chloroform fumigated and nonfumigated soils by dichromate digestion method described by Vance et al., (1987). The $\mathrm{MBC}$ was estimated from the equation: $\mathrm{MBC}=2.64 \mathrm{Ec}$, where $\mathrm{Ec}$ is the difference between organic carbon extracted from the $\mathrm{K}_{2} \mathrm{SO}_{4}$ extract of fumigated and nonfumigated soils. Another portion of the sieved soils were air dried (2-3 days) and used for determination of $\mathrm{pH}$, water holding capacity, organic carbon, available N, P and K (Page et al., 1982). Undisturbed core samples from each layer were collected with a core sampler 
(5.0 cm diameter) for determination of soil bulk density (Blake et al., 1986). The nutrient concentrations of both main product and by product of banana and intercrops were estimated by standard procedures.

Five random plants were selected from each treatment for recording observation. Data recorded were statistically analyzed for all quantitative characters. Intercrop yields in terms of equivalent banana yield has been derived by the following formula:

Banana equivalent yield (BEY) from intercrop $(\mathrm{t}$ ha-1) $=($ Yield of intercrop ( $\mathrm{t}$ ha-1) $\mathrm{x}$ Sale price of intercrop (Rs. $t-1)$ )/Sale rate of banana (Rs. t-1)

Total banana equivalent yield from the complete crop cycle have been worked out for comparison among the treatments. For economic analysis cost of all the inputs in the local market and sale price of produce at the farm gate has been used.

\section{Results and Discussion}

\section{Nutrient uptake}

The nutrient uptake of banana and different intercrops are presented in Table 1. The nitrogen removal was maximum in banana + cowpea intercropping system $\left(317.5 \mathrm{~kg} \mathrm{ha}^{-1}\right)$ and was minimum in sole cropping of banana $\left(168.9 \mathrm{~kg} \mathrm{ha}^{-1}\right)$. Green manuring of banana with Glyricidia maculeata leaves resulted in the nitrogen uptake in banana $\left(212.5 \mathrm{~kg} \mathrm{ha}^{-1}\right)$ and among intercrops, legumes removed maximum nitrogen of 109.2 and $93.5 \mathrm{~kg} \mathrm{ha}^{-1}$, in cowpea and horsegram, respectively. The phosphorus uptake of different banana based cropping systems exhibited similar trend as that of nitrogen. Addition of green manure or intercropping with cowpea enhanced phosphorus uptake in banana and the increase was to the tune of $12.9 \%$ over the control plot of sole banana $\left(18.9 \mathrm{~kg} \mathrm{ha}^{-1}\right)$. Intercropping of legumes in banana resulted in the highest phosphorus removal from the system with values of 34.5 and $33.7 \mathrm{~kg} \mathrm{ha}^{-1}$ in banana + cowpea and banana + horsegram, respectively. Enrichment of the soils with green manuring also enhanced the potassium uptake of banana to the maximum (321.6 kg ha ${ }^{-1}$ ) as compared to other systems. Intercropping of legumes exhibited the highest system uptake of potassium accounting $393.6 \mathrm{~kg} \mathrm{ha}^{-1}$ for banana + cowpea and $388 \mathrm{~kg} \mathrm{ha}^{-1}$ for banana + horsegram. Enhanced uptake of nutrients by banana legume intercropping systems has also been reported by McIntyre et al., (2001).

\section{Soil properties}

The soil organic carbon (SOC) content (Table 2) was maximum in green manuring with Glyricidia $\left(8.3 \quad \mathrm{~g} \quad \mathrm{~kg}^{-1}\right)$ followed by intercropping of cowpea (7.8 $\mathrm{g} \mathrm{kg}^{-1}$ ) and horsegram $\left(7.7 \mathrm{~g} \mathrm{~kg}^{-1}\right)$. Green manuring and legume intercropping helped in buildup of SOC and the elevation was to the tune of 28.3 - $38.3 \%$ over the initial status $\left(6.0 \mathrm{~g} \mathrm{~kg}^{-1}\right)$. Increase in SOC contents in the soil due to green foliage lopping of Glyricidia has also been observed by Vanilarasu and Balakrishnamurthy (2014). Buildup of SOC contents in legume intercropping is attributed to the accumulation of root residues and shedding effect of leaves (Shalini Pillai et al., 2007). Banana based cropping systems did not have any significant effects on $\mathrm{pH}$, bulk density and water holding capacity of the soils at the end of second cropping cycles. However, marginal improvement in bulk density and water holding capacity of the soils were noticed with green manuring and legume intercropping. Green manuring in banana with leaves of Glyricidia enhanced the MBC to the maximum (208.9 $\mu \mathrm{g} \mathrm{C} \mathrm{g}^{-1}$ soil) and the increase was to the tune of $62.8 \%$ over the initial status $\left(128.3 \mu \mathrm{g} \mathrm{C} \mathrm{g}^{-1}\right.$ soil). 
Table.1 Nutrient uptake as influenced by banana based intercrops (data pooled over two years)

\begin{tabular}{|c|c|c|c|c|c|c|c|c|c|}
\hline \multirow[t]{2}{*}{ Treatments } & \multicolumn{3}{|c|}{$\begin{array}{l}\text { Nitrogen uptake } \\
\left(\mathrm{kg} \mathrm{ha}^{-1}\right)\end{array}$} & \multicolumn{3}{|c|}{$\begin{array}{c}\text { Phosphorus uptake } \\
\left(\mathrm{kg} \mathrm{ha}^{-1}\right)\end{array}$} & \multicolumn{3}{|c|}{$\begin{array}{l}\text { Potassium uptake } \\
\left(\mathrm{kg} \mathrm{ha}^{-1}\right)\end{array}$} \\
\hline & Main crop & Intercrop & Total & Main crop & Intercrop & Total & Main crop & Intercrop & Total \\
\hline Banana + Cowpea & 208.3 & 109.2 & 317.5 & 21.7 & 12.8 & 34.5 & 319.1 & 74.5 & 393.6 \\
\hline Banana + Bottle gourd & 190.3 & 62.7 & 253.0 & 17.8 & 10.6 & 28.4 & 296.8 & 66.7 & 363.5 \\
\hline Banana + Sweet potato & 191.1 & 67.5 & 258.6 & 18.5 & 10.9 & 29.4 & 291.3 & 64.4 & 355.7 \\
\hline Banana (Control) & 168.9 & - & 168.9 & 18.9 & - & 18.9 & 281.8 & - & 281.8 \\
\hline $\operatorname{SEm}( \pm)$ & & & 10.17 & & & 2.897 & & & 14.433 \\
\hline $\mathrm{CD}(\mathrm{P}=0.05)$ & & & 20.95 & & & 5.97 & & & 29.73 \\
\hline
\end{tabular}

Table.2 Effect of banana based cropping system on soil properties

\begin{tabular}{|c|c|c|c|c|c|}
\hline Treatments & $\begin{array}{c}\text { pH } \\
(1: 2.5)\end{array}$ & $\begin{array}{c}\text { BD } \\
\left(\mathrm{Mg} \mathrm{m}^{-3}\right)\end{array}$ & $\begin{array}{l}\text { WHC } \\
(\%)\end{array}$ & $\begin{array}{c}\mathrm{SOC} \\
\left(\mathrm{g} \mathrm{kg}^{-1}\right)\end{array}$ & 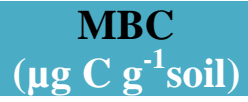 \\
\hline Banana + Cowpea & 5.45 & 1.43 & 46.4 & 7.8 & 192.4 \\
\hline Banana + Horse gram & 5.44 & 1.43 & 46.0 & 7.7 & 190.2 \\
\hline Banana + Bottle gourd & 5.48 & 1.45 & 44.6 & 6.5 & 158.4 \\
\hline Banana + Sweet potato & 5.49 & 1.45 & 44.2 & 6.4 & 154.2 \\
\hline Banana + Glyricidiamaculeata & 5.42 & 1.42 & 47.2 & 8.3 & 208.9 \\
\hline Banana + Polythene mulch & 5.50 & 1.47 & 43.4 & 6.2 & 138.4 \\
\hline Banana (Control) & 5.51 & 1.46 & 43.1 & 6.1 & 136.8 \\
\hline $\operatorname{SEm}( \pm)$ & 0.078 & 0.016 & 1.718 & 0.280 & 5.883 \\
\hline $\mathrm{CD}(\mathrm{P}=\mathbf{0 . 0 5})$ & NS & NS & NS & 0.86 & 18.13 \\
\hline Initial status & 5.53 & 1.46 & 43.1 & 6.0 & 128.3 \\
\hline
\end{tabular}

BD: Bulk density, WHC: Water holding capacity, SOC: Soil organic carbon, MBC: Microbial biomass carbon 
Table.3 Balance nutrient status of the soils as influenced by banana based intercrops

\begin{tabular}{|c|c|c|c|c|c|c|c|c|c|}
\hline \multirow[t]{2}{*}{ Treatments } & \multicolumn{3}{|c|}{ Nitrogen $\left(\mathrm{kg} \mathrm{ha}^{-1}\right)$} & \multicolumn{3}{|c|}{ Phosphorus (kg ha-1) } & \multicolumn{3}{|c|}{ Potassium (kg ha $\left.{ }^{-1}\right)$} \\
\hline & Initial & Final & $\begin{array}{c}\text { Gain/ } \\
\text { loss }\end{array}$ & Initial & Final & $\begin{array}{c}\text { Gain/ } \\
\text { loss }\end{array}$ & Initial & Final & $\begin{array}{c}\text { Gain/ } \\
\text { loss }\end{array}$ \\
\hline Banana + Cowpea & 273.1 & 297.4 & 24.3 & 10.5 & 10.3 & -0.2 & 93.6 & 89.4 & -4.2 \\
\hline Banana + Horse gram & 273.1 & 291.6 & 18.5 & 10.5 & 10.2 & -0.3 & 93.6 & 88.6 & -5.0 \\
\hline Banana + Bottle gourd & 273.1 & 270.5 & -2.5 & 10.5 & 10.1 & -0.4 & 93.6 & 90.7 & -2.9 \\
\hline Banana + Sweet potato & 273.1 & 268.2 & -4.9 & 10.5 & 9.9 & -0.6 & 93.6 & 88.6 & -5.0 \\
\hline Banana+ Glyricidiamaculeata & 273.1 & 306.4 & 33.3 & 10.5 & 14.0 & 3.4 & 93.6 & 109.4 & 15.8 \\
\hline Banana + Polythene mulch & 273.1 & 272.2 & -1.1 & 10.5 & 9.2 & -1.3 & 93.6 & 88.8 & -4.8 \\
\hline Banana (Control) & 273.1 & 263.8 & -9.3 & 10.5 & 9.1 & -1.4 & 93.6 & 87.4 & -6.2 \\
\hline $\operatorname{SEm}( \pm)$ & & 7.267 & & & 0.844 & & & 6.047 & \\
\hline $\mathrm{CD}(\mathrm{P}=0.05)$ & & 22.39 & & & 2.60 & & & NS & \\
\hline
\end{tabular}

Table.4 Yield and return from the complete cycle of crops (pooled data of two years)

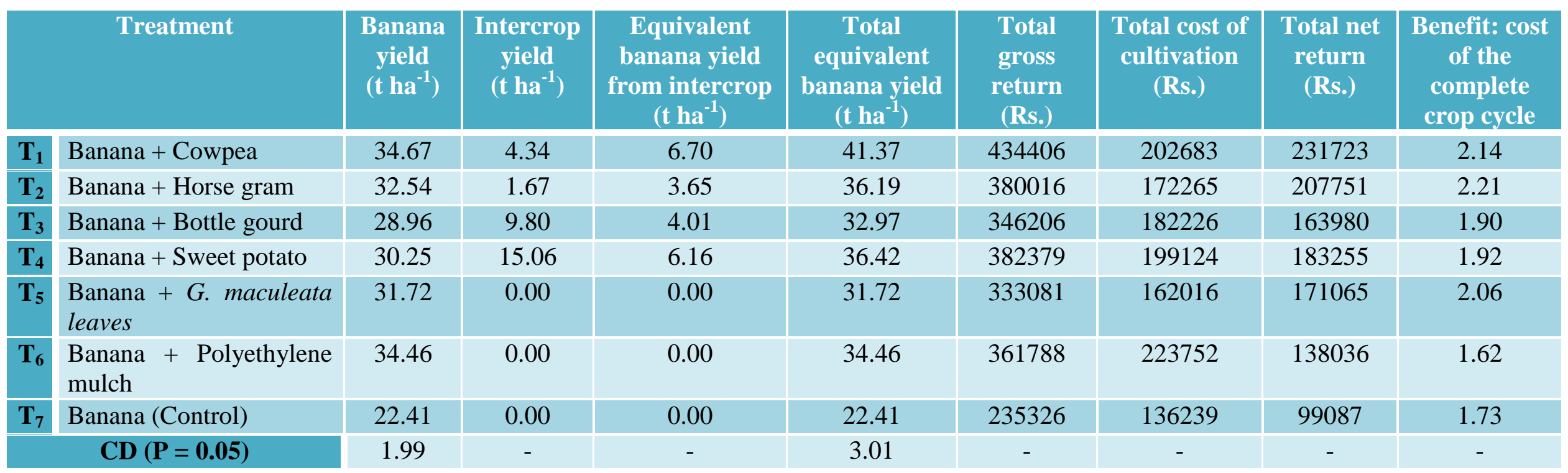


Fig.1 Effect of banana based cropping systems on microbial quotient of soils

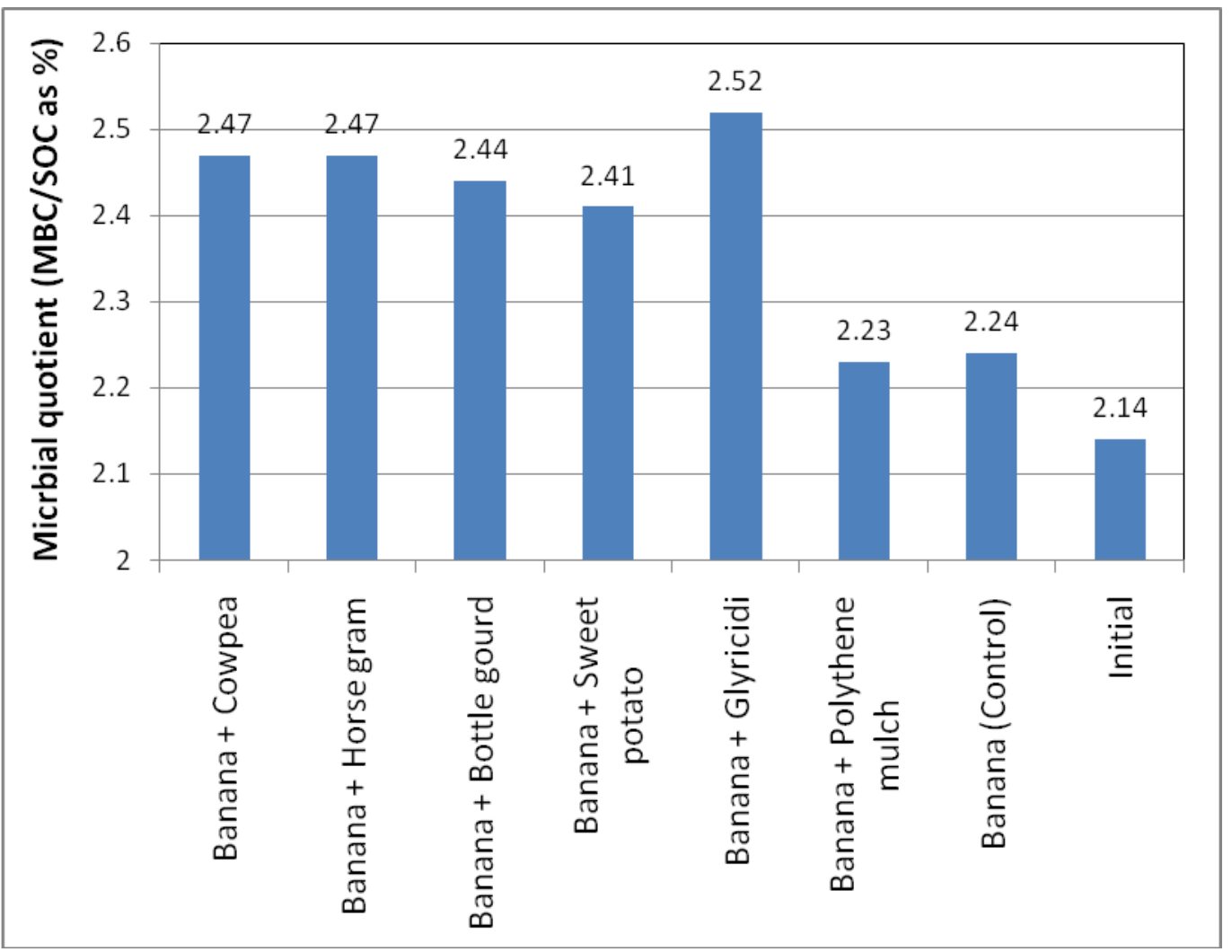

Legume intercropping in banana also increased the MBC of soils by 48.2 to 50.0 per cent. Elevated $\mathrm{MBC}$ of the soils are related to the increased soil organic matter contents that supply substrate $\mathrm{C}$ for proliferation of microbial population in the soil (Singh et al., 2008). The supply of additional mineralizable $\mathrm{C}$ due to increased organic matter results in higher microbial activity and thus higher MBC (Ingle et al., 2014). The ratio of MBC to SOC expressed as ratio or percentage is known as microbial quotient and is very often used as a measure of $\mathrm{C}$ availability to micro-organisms. The microbial quotient of different banana based cropping systems is presented in Figure 1. Banana with Glyricidia green manuring registered the highest microbial quotient of 2.52 followed by the intercropping of legumes (2.47 each with cowpea and horsegram). Higher microbial quotient of these soils is related to higher substrate availability through accumulation of organic matter in the soils (Jacobs et al., 2009).

\section{Balance nutrient status of the soil}

The residual nutrient status of the soils after two years of different banana based cropping systems is presented in Table 3. Growing of Glyricidia as a green manure crop in banana elevated the available $\mathrm{N}, \mathrm{P}$ and $\mathrm{K}$ contents of the soil and the gain was to the tune of 33.3, 3.4 and $15.8 \mathrm{~kg} \mathrm{ha}^{-1}$, respectively over the initial contents of $273.1 \mathrm{~kg} \mathrm{ha}^{-1} \mathrm{~N}, 10.5 \mathrm{~kg} \mathrm{ha}^{-}$ ${ }^{1} \mathrm{P}$ and $93.6 \mathrm{~kg} \mathrm{ha}^{-1} \mathrm{~K}$. Inclusion of legumes like cowpea and horsegram also improved the available $\mathrm{N}$ contents with gain of 24.3 and $18.5 \mathrm{~kg} \mathrm{ha}^{-1}$, respectively. Increase in available $\mathrm{N}, \mathrm{P}$ and $\mathrm{K}$ contents of the soils with green manuring is due to the decomposition of organic matter and converting the organic 
bound nutrients to inorganic forms during mineralization (Vanialarasu and Balakrishnamurthy, 2014). Inclusion of legumes has contributed higher nitrogen fixation resulting in availability of more residual $\mathrm{N}$ in the soils (Himmatrao et al., 2014). However, there was mining of available soil $\mathrm{P}$ and $\mathrm{K}$ as they were actively utilized by both banana and intercrops.

\section{Yield}

The banana bunch yield was in the range of a lowest $22.41 \mathrm{t} \mathrm{ha}^{-1}$ in $\mathrm{T}_{7}$ to a highest $34.67 \mathrm{t}$ $\mathrm{ha}^{-1}$ in $\mathrm{T}_{1}$ (Table 4). Highest banana bunch weight with cowpea was at par with that under polyethylene mulch. High bunch yield under polythene mulch was observed due to very less incidence of weeds which is confirmed by Paul et al., (2008) and Solia et al., (2010). Increased bunch yield from banana plants intercropped with cowpea was probably due to increased nitrogen availability through nitrogen fixation by their root nodules in the soil.

\section{Economics}

The results show a significant difference among the treatments in total BEY from the complete cycle of crops (Table 4). $\mathrm{T}_{1}$ achieved a significantly highest yield of 41.37 $\mathrm{t} \mathrm{ha}^{-1}$ followed by $\mathrm{T}_{2}$ with $36.19 \mathrm{t} \mathrm{ha}^{-1}$, whereas, $\mathrm{T}_{7}$ showed the least $\left(22.41 \mathrm{t} \mathrm{ha}^{-1}\right)$. Following a similar trend, $\mathrm{T}_{1}, \mathrm{~T}_{2}$ and $\mathrm{T}_{7}$ could generate a total net return of Rs. $231723 \mathrm{ha}^{-1}$, Rs. $207751 \mathrm{ha}^{-1}$ and Rs. $99087 \mathrm{ha}^{-1}$, respectively. But, a critical economic analysis of the complete crop cycle indicated that the highest benefit: cost ratio (return per rupee investment) of 2.21 is obtained in $\mathrm{T}_{2}$ followed by 2.14 in $T_{1}, 2.06$ in $T_{5}$ and a lowest of 1.62 in $\mathrm{T}_{6}$. The lowest $\mathrm{C}$ : $\mathrm{B}$ ratio under polyethylene mulch is due to the high cost of cultivation from polyethylene mulch sheets and no returns from any intercrop. Similar results have also been reported by Jain and Raut (2004).

The study on the effect of intercrops on banana based intercropping systems revealed that inclusion of green manures in the cropping system is beneficial in improving SOC, MBC and available nutrients of the soil and maintaining overall soil quality. Banana with legume intercrops, though improved the SOC and available $\mathrm{N}$ of the soils, there was depletion of available $\mathrm{P}$ and $\mathrm{K}$ from the soils. In accordance with the improvement in soil qualities and nutrient status the leguminous vegetable cowpea could yield highest total banana equivalent yield $\left(41.37 \mathrm{t} \mathrm{ha}^{-1}\right)$ and fetch highest net return (Rs. $231723 \mathrm{ha}^{-1}$ ) whereas horsegram could achieve highest cost: benefit ratio (2.21) in view of its low cost of cultivation.

\section{References}

Blake, G.R., Hartge, K.H., 1986. Bulk Density. In: Klute, A. (Ed.), Methods of Soil Analysis. Part 1: Physical and mineralogical methods, 2nd edition. : Agronomy Monograph No. 9. Soil Science Society of America. Madison, Wisconsin, 363-375.

Himmatrao, M. S., Raghavaiah, R., Malamasuri, K. and Soumya, B. 2014. Influence of row ratio and zinc levels on yield, nutrient uptake and soil fertility status of maize (Zea mays L.)-soybean (Glycine max L.) intercropping systems under rainfed conditions. Journal of Progressive Agriculture 5(1): 39-42.

Ingle, S. S., Jadhao, S. D., Kharche, V. K., Sonune, B. A. and Mali, D. V. 2014. Soil biological properties as influenced by long term manuring and fertilization under sorghum (Sorghum bicolor) wheat (Triticum aestivum) sequence in Vertsols. Indian Journal of Agricultural Sciences 84(4): 16-21. 
Jacobs, A., Rauber, R. and Ludwig, B. 2009. Impact of reduced tillage on carbon and nitrogen storage of two Haplic Luvisols after 40 years. Soil and Tillage Research 102: 158-164.

Jain, P.K. and Raut, R.L. 2004. Influence of intercrops on yield attributes and land equivalent ratio of mango (Mangifera indica). In: First Indian Horticulture Congress (Abstr.), 6-9 November, 2004, Pusa, New Delhi, pp: 171.

McIntyre, B. D., Gold, C S., Kashaija, I. N., Ssali, H., Night, G. and Bwamiki, D. P. 2001. Effects of legume intercrops on soil borne pests, biomass, nutrients and soil water in banana. Biology and Fertility of Soils, 34: 342-348.

Page, A. L., Miller, R. H. and Keeney, D. R. 1982. Methods of soil analysis, Part-II. American Society of Agronomy, Inc Publisher, Madison, Wisconsin, USA.

Paul, J.C., Mishra, J.N. and Pradhan, P.L. 2008. Response of banana to drip irrigation and mulching in coastal Orissa. Journal of Agricultural Engineering; 45 (4): 44-49.

Shalini Pillai, P., Geethakumari, V. L. and Rebecca Issac, S. 2007. Balance sheet of soil nitrogen in rice (Oryza sativa) based cropping systems under integrated nutrient management. Indian Journal of Agronomy, 52 (1): 16-20.
Singh, A. B., Ramesh, P., Panwar, N. R. and Ramana, S. 2008. Nutritional quality of soybean (Glycine max), wheat (Triticum durum) and chickpea (Cicer arietinum) and soil biological properties as influenced by different organic manures. Indian Journal of Agricultural Sciences 78 (9): 47-50.

Solia, B.M., Alkade, S.A., Patil, S.J., Patel, A.P., Mallik, M.S., Dhimmar, S.K. and Patil, R.G. 2010. Studies on efficient use of water and nutrients in banana under South Gujarat conditions. Green Farming, 1 (1): 59-61.

Vance, E. D., Brookes, P. C. and Jenkinson, D. S. 1987. An extraction method for measuring soil microbial biomass carbon. Soil Biology and Biochemistry, 19: 703-706.

Vanilarasu, K. and Balakrishnamurthy, G. 2014. Influence of organic manure and amendments in soil physico-chemical properties and their impact on growth, yield and nutrient uptake of banana. The Bioscan, 9 (2): 525-529.

Yadukumar, N. 2007. Development of sustainable cashew based cropping systems- Inter and mixed cropping with cashew. National Seminar on Research, Development and Marketing of Cashew, 20-21 Nov., 2007, Goa. Souvenir and Extended Summaries. pp.62.

\section{How to cite this article:}

Dash, S.N., S. Behera, Y. Pushpavathi and Mishra, K.N. 2018. Conservation Agriculture Approaches in Banana to Improve Soil Quality and Farm Productivity. Int.J.Curr.Microbiol.App.Sci. 7(03): 651-658. doi: https://doi.org/10.20546/ijcmas.2018.703.076 